BULLETIN Bulletin hispanique

HISPANIQUE Université Michel de Montaigne Bordeaux

114-2 | 2012

Varia

\title{
Paralelismos y concomitancias entre las relaciones de sucesos hispánicas y las coplas sefardíes
}

\section{María Sánchez Pérez}

\section{(2) OpenEdition \\ 1 Journals}

Edición electrónica

URL: https://journals.openedition.org/bulletinhispanique/2005

DOI: 10.4000/bulletinhispanique.2005

ISSN: $1775-3821$

Editor

Presses universitaires de Bordeaux

Edición impresa

Fecha de publicación: 31 diciembre 2012

Paginación: 541-560

ISBN: 978-2-86781-855-4

ISSN: 0007-4640

Referencia electrónica

María Sánchez Pérez, «Paralelismos y concomitancias entre las relaciones de sucesos hispánicas y las coplas sefardíes», Bulletin hispanique [En línea], 114-2 | 2012, Publicado el 05 enero 2016,

consultado el 29 julio 2022. URL: http://journals.openedition.org/bulletinhispanique/2005 ; DOI:

https://doi.org/10.4000/bulletinhispanique.2005

All rights reserved 


\title{
Paralelismos y concomitancias entre las relaciones de sucesos hispánicas y las coplas sefardíes
}

\author{
María SÁNChez PÉREz \\ CSIC - Madrid
}

L'objectif de cet article est de mettre en évidence les similitudes et les parallèles entre les relations d'événements hispaniques («relaciones de sucesos») et les chants Sépharades ("coplas sefardíes»). Les échantillons qui nous sont parvenus de chants judéo-espagnols de différentes époques montrent qu'il existe des interconnexions entre ceux-ci et leurs "sours" d'origine hispanique. Ces ouvrages partagent certaines caractéristiques observables dans les aspects poétiques et rhétoriques, mais aussi pour les thèmes et contenus.

Mots-clés: relations d'événements, chants sépharades, littérature populaire, littérature sépharade.

El objetivo de este articulo es poner de manifiesto las semejanzas y los paralelismos existentes entre las relaciones de sucesos hispánicas y las coplas sefardies. Las muestras que hemos conservado de coplas en judeoespañol aljamiado de diferentes épocas demuestran que existen interconexiones entre ellas y sus "hermanas" hispánicas. Estas obras comparten algunas características en común que se aprecian en sus aspectos poético-retóricos, pero también en muchos de los temas y contenidos tratados.

Palabras clave: relaciones de sucesos, coplas sefardíes, literatura popular, literatura sefardí.

The aim of this paper is to highlight the similarities and parallels between the narration of special Spanish event "relaciones de sucesos» and Sephardic songs "coplas sefardíes". The samples that have been preserved in Judeo-Spanish songs from different periods show the interconnections between them and their Hispanic "sisters". These works share some characteristics that can be observed in their poetic and rhetorical aspects, but also in many of the themes and contents.

Keywords: narration of special events, Sephardic Coplas, popular literature, Sephardic literature. 
$\mathrm{D}$ esde la expulsión de los más de cien mil judíos de los reinos de Castilla y Aragón en 1492 la vida sociocultural y literaria de los sefardíes se fue creando y consolidando en los diferentes países en los que se asentaron tras la diáspora, fundamentalmente en las zonas del entonces pujante Imperio otomano, pero también en diferentes países de Europa -Portugal, Francia, Italia, etc.- o en el reino de Marruecos (como estudios de conjunto pueden verse, entre otros, Méchulan 1993; Benbassa \& Rodrigue 2000).

Dentro de la producción literaria en judeoespañol $y$, atendiendo especialmente a su temática y finalidad, cabe destacar dos grupos: por una parte, encontramos una literatura patrimonial, propiamente sefardí, de carácter religioso fundamentalmente; por otra, hallamos una literatura adoptada, de carácter secular e influida por Occidente. A estos grandes grupos, cabría unir «la literatura transmitida, es decir, los géneros tradicionales de transmisión principalmente oral» (Romero 1992: 22-23).

La producción literaria en lengua vernácula de los sefardíes puede dividirse, además, en dos áreas bien diferenciadas: por una parte, la zona turco-balcánica y, por otra, el norte de África. Durante los siglos XVI y XVII la creación literaria en judeoespańol se basa, principalmente, en traducciones de la Biblia y de textos litúrgicos, pero se producirá un giro radical a partir del siglo XVIII, que puede ser considerado como la Edad de Oro de la literatura sefardí -como detallaremos más adelante. Otro período clave de la producción en judeoespañol será el siglo XIX, especialmente a mitad de la centuria, ya que se observa una influencia clara de Occidente en el mundo cultural sefardí, de ahí que surjan los llamados géneros adoptados, que no contaban con precedentes en la cultura judía anterior. En un afán por imitar estos géneros comienzan a publicarse en judeoespañol novelas, obras de teatro, publicaciones periódicas, etc. No obstante, toda esta producción cultural y literaria se vio brutalmente truncada con la Segunda Guerra Mundial, el Holocausto nazi y las migraciones posteriores.

Como apuntábamos más arriba, hubo un florecimiento de la literatura en judeoespañol en el Mediterráneo oriental en el siglo XVIII, de ahí que se le considere el Siglo de Oro de las letras sefardíes: "Se redactó en esta época la magna enciclopedia del saber rabínico: el Méam lo éz; se publicaron numerosos libros de contenido religioso; y se desarrolló espléndidamente el género poético de las coplas» (Díaz-Mas 2006: 78), siendo, este último, el género «donde se remansa la más genuina y castiza producción poética sefardí» (Romero 1992: 141). Las características principales de estas coplas, complas o conplas son las siguientes:

Se trata de poemas: $a$ ) estróficos, b) con frecuencia acrósticos, c) cantables, $d$ ) de variada temática, pero habitualmente narrativos o descriptivos (no líricos), e) de origen culto, $f$ ) de transmisión primordialmente libresca (aunque algunos hayan sido adoptados por la tradición oral), g) su distribución geográfica abarca Oriente y Marruecos y h) su historia documentada va desde el siglo xviII hasta el xx, aunque algún caso hay de coplas de finales del siglo Xviı (Díaz-Mas 2006: 160). 
Estas composiciones tienen una raigambre medieval, ya que «los autores de las coplas sefardíes parece que se basaron en una tradición previa, de origen hispanojudío medieval. Así lo sugieren la coincidencia de rasgos formales y de contenido» (Díaz-Mas 1994: 19). Sin embargo, no podemos concretar cuándo se inició este género de las coplas. Las primeras ediciones que conservamos son del siglo XVIII, pero -como señalan los expertos- no parece viable que el género de las coplas existiera sin una tradición anterior:

Las primeras ediciones por nosotros conocidas nos lo muestran ya en los albores del siglo XVIII como un género pujante, rico y vigorosamente enraizado en la tradición. Tan pujante y vigoroso se muestra que el investigador debe plantearse serias dudas a la hora de decidir si nace por generación espontánea en el siglo XviII o si, a pesar de la ausencia de documentación textual, su origen debe remontarse en el tiempo, ya que no es un hecho acostumbrado que las primeras manifestaciones «manifiestas» de un género coincidan casi con su época de máximo esplendor y tampoco es habitual que alcance su apogeo sin una andadura previa (Romero 1992: 146).

Estas coplas abarcan diversos contenidos y temáticas pues, al fin y al cabo, en ellas se expresa cualquier asunto que se refiera o incumba a los judíos, en general, o a los sefardíes, en particular. Existen coplas paralitúrgicas -que se cantan en las celebraciones de determinadas festividades del ciclo litúrgico-, admonitivas, morales o de castiguerio, del felek (tc. «mundo, siglo, actualidad») -que conllevan una crítica de las costumbres modernas-, hagiográficas, etc. (Díaz-Mas 2006: 163-165). Sin embargo, nuestra atención se va a centrar ahora especialmente en las coplas históricas o noticieras, ya que son las que hemos comprobado que presentan una serie de similitudes y concomitancias con las que podríamos denominar como sus «hermanas hispánicas»: las relaciones de sucesos.

Estas últimas comenzaron a imprimirse en Espańa, fundamentalmente a partir del siglo XvI, cuando una fiebre informativa recorre casi todos los países de Europa, de ahí que encontremos en lugares como Francia, Italia, Inglaterra o Portugal fenómenos culturales parecidos en esas mismas fechas. Las relaciones de noticias y sucesos conocieron en la península Ibérica un apogeo masivo en el siglo XVII y, a partir del XVIII, estos especímenes protoperiodísticos convivieron con las gacetas y, por lo tanto, con el nacimiento de la prensa periódica. No obstante, cabe destacar que en España la venta y difusión de las relaciones convivió largamente con los nuevos géneros periodísticos, llegó hasta el siglo Xx e incluso, en algunos casos, hasta el xxI (Sánchez Pérez, 2011).

Es nuestro propósito presentar aquí un estudio que muestre los paralelismos y concomitancias existentes entre las relaciones de sucesos hispánicas y las sefardíes $^{1}$, especialmente desde un punto de vista formal, atendiendo, por lo tanto, a diversos aspectos poético-retóricos que, como veremos, aparecen tanto en nuestras de relaciones de sucesos en castellano como en judeoespañol ${ }^{2}$. En

1. Existen ya acercamientos a este tema, véase el imprescindible trabajo de Pedrosa 1995.

2. Este trabajo es producto de mi contrato Juan de la Cierva en el Consejo Superior de Investigaciones Científicas (CSIC), dentro del proyecto de investigación «Los sefardíes ante 
ambos casos nos ceñiremos a relaciones de sucesos en verso. En este sentido, cabe destacar que, por lo que se refiere a los textos castellanos, aunque también aparecieron obras de este tipo en prosa, fue en la forma versificada como proliferaron y alcanzaron mayor difusión ${ }^{3}$. En el caso de las relaciones de sucesos hispánicas tomaremos como ejemplos diversas piezas del siglo XVI, mientras que en el caso de las relaciones de noticias sefardíes tomaremos como obra de referencia la monografía de Elena Romero (2008), Entre dos (o más) fuegos. Fuentes poéticas para la historia de los sefardies de los Balcanes, ya que se trata de un vasto y magnífico estudio de coplas sefardíes relativas a sucesos históricos comprendidos entre mediados del siglo xvir y los inicios de la Segunda Guerra Mundial. En total, la profesora Romero incluye ciento ochenta y dos textos -la mayor parte de ellos inéditos-, cuyas fuentes son impresas, manuscritas principalmente aljamiadas, aunque hay también latinadas- y orales, y proceden de un amplio espectro geográfico: Salónica, Esmirna, Constantinopla, Belgrado, Sarajevo, Jerusalén, Venecia, Nueva York, Miami, etc. Todas estas coplas en judeoespañol reflejan:

(a) las vivencias de los sefardíes - minoría inmersa dentro de una sociedad mayoritaria ajena-involucrados en los acontecimientos históricos que tuvieron lugar en el Imperio otomano y en el mundo balcánico surgido tras su desmembración; así como también (b) sus relaciones con el poder, ya sea éste central o local; en contadas ocasiones y sólo por dejar aquí unas breves pinceladas de muestra, incluyo también (c) algunos textos de lo que podría considerarse historia social (Romero 2008: 21).

Tomando como ejemplo las relaciones de sucesos hispánicas, según Víctor Infantes: «una 'relación' es un impreso breve de carácter informativo de carácter no periódico» (Infantes 1996: 211). De sus palabras podemos deducir que cualquier acontecimiento que tenga una mínima base histórica o verosímil puede ser el origen de una relación de sucesos. Es decir, cualquier hecho que fuese noticiable, y con ello, susceptible de ser difundido podría dar forma a una de estas relaciones. Lo noticiable debe ser interesante para el público -ya sea oyente o lector-, puesto que es él quien decide voluntariamente leer u oír un suceso determinado. Se trata, en definitiva, de documentos que narran hechos ocurridos realmente o ficticios - pero siempre verosímiles- que pretenden informar, entretener y/o conmover al público. Como señalaba Pedro M. Cátedra:

sí mismos y en sus relaciones con España» II, (FFI2009-07026) del Ministerio de Ciencia e Innovación.

3. Señalaba Henry Ettinghausen (1996: 61-62): «Muchas de las relaciones en verso de acontecimientos públicos [...] pueden considerarse como versiones popularizantes de las relaciones en prosa y de gran parte de la poesía culta producida por las academias literarias. Sin embargo, hay temas que se desarrollan exclusivamente en relaciones en verso, en especial los crímenes violentos que siguen relatándose en pliegos poéticos tremendistas casi hasta nuestros días». 
La necesidad y, por consiguiente, la existencia de la relación oral o escrita de hechos particulares es tan antigua como la facultad inherente al individuo de la curiosidad, sus relaciones sociales o el menester que las instituciones han tenido siempre de recibir o transmitir información (Cátedra 1996: 33).

Esa necesidad de comunicarse que siente el ser humano, ya sea como un acto social o por la necesidad de transmitir conocimientos, es consustancial a nuestra especie, de ahí el nacimiento de estas relaciones de sucesos. La transmisión de noticias comenzó haciéndose de forma verbal, pasó luego a la forma manuscrita y, gracias a la invención de la imprenta, también a la forma impresa. No obstante, ello no supuso que unas formas desterraran a otras, sino que las tres convivieron durante siglos (véase Bouza 2001) y, habitualmente, a las relaciones de sucesos se las considera antecesoras de la prensa actual.

Las relaciones de sucesos hispánicas que tomamos como ejemplo se imprimeron en pliegos de cordel que, como sabemos, se caracterizan por su condición efímera, ya que se utilizaba un papel basto, de mala calidad. Además, no estaban encuadernados, ya que no se concebían para perdurar en el tiempo y su coste era bastante bajo. De manera semejante, la mayor parte de estas coplas sefardíes se imprimeron en libros aljamiados, también impresos de escasas páginas y de bajo precio, por ello «estaban [...] al alcance de todos, y se utilizaban para aprender de memoria esos poemas y cantarlos" (DíazMas 1994: 20). De ahí también que ambos fenómenos estén muy ligados a la oralidad -como veremos más adelante-.

$M^{a}$. Cruz García de Enterría codificó una «retórica menor», basándose en fuentes escritas de los Siglos de Oro de la literatura española. Para ella «se podría llamar 'retórica menor' a la retórica no codificada, no escrita, pero sí existente en la literatura que llamamos popular» y añadía

Es retórica «consciente», por parte de quien la utiliza porque sabe lo que quiere decir y usa tópicos, fórmulas o modelos de discurso aunque no sepa dar una descripción sistemática del método que ha seguido. Es, pues, la retórica que se da en las manifestaciones literarias de una sociedad de cultura básicamente oral (García de Enterría 1990a: 271).

Las apreciaciones que la profesora García de Enterría observa respecto a la literatura popular española son, en parte, asimilables a las coplas narrativas sefardíes que conservamos de tema histórico. No podemos obviar, sin embargo, que existen diferencias entre las relaciones de sucesos hispánicas y las coplas sefardíes. En el caso de éstas, en muchas ocasiones, conocemos su autoría, mientras que en las composiciones castellanas o bien nos las habemos con piezas anónimas o bien ante autores cuyo origen, con frecuencia, no es culto, al contrario de lo que sucede con las coplas. De ahí que no podamos hablar de una perfecta semejanza entre las relaciones de sucesos hispánicas y sefardíes con respecto a esa retórica menor. Sin embargo, cabe destacar que, en el caso de las coplas sefardíes, existe un proceso de olvido o, como señala Iacob M. Hassán, de «olvidación», ya que los nombres de los autores de muchas de estas 
composiciones se fueron perdiendo, olvidando, a medida que se transmitían estos textos a lo largo de la historia (Hassán 1987).

Sin embargo, el hecho de que ambas manifestaciones fueran cantables o recitables permite que encontremos formulaciones y tópicos semejantes en buena parte de estas obras. De nuevo -como veremos más adelante- la oralidad va a jugar un papel muy importante en los procesos de invención y difusión de estas obras.

Para llevar a cabo nuestro análisis, hemos optado por fijar nuestra atención en tres de las partes en las que la retórica divide su discurso: exordium, narratio y peroratio. Si nos centramos ahora en los principios del discurso, es decir, en el exordio de estas obras, veremos que la función principal es, obviamente, señalar que comienza la narración, así como atraer la atención y fijar el interés del receptor. Veamos algunos ejemplos ${ }^{4}$.

El primer fragmento que presentamos pertenece a una relación de sucesos hispánica donde se nos narra el asesinato de un matrimonio a manos de su criado para poder robarles su dinero. Pertenecería a los llamados «casos horribles y espantosos» que, dentro de las relaciones de sucesos forman un subgénero que tuvo una amplia difusión en pliegos de cordel desde mediados del siglo XvI hasta el xx (incluso el xxI, véase Sánchez Pérez, 2011) y cuyo núcleo temático giraba siempre en torno a la crueldad y la violencia. La obra fue impresa por Gaspar Leget, en Barcelona, en 1600 y comenzaba con los siguientes versos:

Altíssimo Rey, sin par,

Dios eterno, poderoso 5

Podemos comprobar las concomitancias y paralelismos, así como una formulación muy parecida entre el texto anterior y los inicios de la siguiente copla sefardí que narra -según reza el título de Romero- las crueldades de Ismaíl Pachá, visir del sultán Mahmud I (Romero 2008: 98-103). Los hechos históricos corresponden al año 1735 y en esta copla se cuentan las crueldades que cometió dicho personaje contra los judíos, acusándolos de robar joyas y de haber cometido un crimen ritual; por todo ello apresan a los judíos y se les somete a tortura. La invocación inicial reza así:

Enpezar quero alabar al Dio enaltecido ${ }^{6}$

4. Cabe señalar que, los textos narrativos en verso que presenta Elena Romero se hallan ya transcritos y editados, ya que estaban escritos en judeoespañol aljamiado, es decir, con caracteres hebraicos. En el caso de los textos hispánicos seguimos las normas que se especifican en el Proyecto de investigación "Cultura popular y cultura impresa: corpus, edición y estudio de la literatura de cordel de los siglos XVI y XVII» [BFF2003-00011]. Guia para los miembros del equipo y colaboradores, Salamanca, SEMYR, 2003, p. 8-9.

5. Se trata de la entrada 788 de la obra de Rodríguez Mońino 1997 (en adelante RM junto con el número de entrada).

6. Romero 2008: 100 (en adelante ER junto con la página). 
De manera semejante, otra relación de sucesos hispánica, también perteneciente a los casos horribles y espantosos, pero de signo muy distinto al ejemplo anterior, comenzaba:

Dame tu gracia excelente,

Dios, que a ti la pido yo [RM 148.5]

Estos versos iniciales corresponden a una relación impresa también en Barcelona, pero anterior a 1580. En ella se narra el castigo que recibió un mal cristiano por no confesarse. Tenemos que recordar que, en la península Ibérica, tras el Concilio de Trento, una de las directrices que había impuesto la Iglesia era la gracia que se obtenía con la confesión y la posterior comunión. El miedo y el rechazo hacia herejes, luteranos, musulmanes, etc. propició en la Península un clima de odio hacia todas las demás confesiones. El título de la obra resume a la perfección el contenido de la misma: Aqui se sigue una obra nuevamente hecha sobre un mal hombre que estuvo doze años sin confessarse y recibió el Sanctíssimo Sacramento del altar sin confessión, por lo qual, y por otras maldades, un demonio visiblemente lo ahogó y se lo llevó.

Si continuamos comparando los exordios de estas composiciones, veremos que fórmulas semejantes a las anteriores se muestran en los primeros versos de esta copla sefardí:

Enpezar quero contar en esta cantiga,

el que la oye cantar que el Dio bendiga [ER 121]

De signo algo distinto a las obras que hemos visto anteriormente, esta invocación -junto con el propósito de comenzar a cantar o componer la narración, muy frecuente también en las relaciones de sucesos hispánicasprocede de una copla en la que se narra el primer asedio de Tiberíades, compuesta por Ya'acob Berab.

Desde siempre, los autores de cualquier obra literaria pedían inspiración, ánimo o fuerza para acometer su tarea a alguna deidad o a las musas, por ejemplo. Hemos comprobado que en las relaciones de sucesos hispánicas que conservamos en verso, del siglo XVI, no es frecuente el ruego a estas últimas y, en las coplas sefardíes, en ningún caso. Lo que sí es habitual tanto en las obras en judeoespañol como en castellano es la invocación divina; en los casos de estas últimas abundan los exordios dedicados a Dios, Jesucristo, la Virgen, la santísima trinidad, etc., mientras que en el judaísmo la imploración o invocación se dirigirá -como es obvio- al Dios único de los judíos.

Por otro lado, no es infrecuente tampoco que las composiciones comiencen sin esas invocaciones, sin introducción alguna, y la técnica de la que se valen los autores en estos casos es la de situar cronológicamente los hechos que se van a narrar. Así, por ejemplo, encontramos en dos relaciones de sucesos castellanas -una de Alonso de Ercilla sobre una victoria militar hispánica, ca. 1552; otra sobre un incendio de una nave que se dirigía a las Indias, compuesta por Hernando de Verduras en 1553- los siguientes versos: 
A los veinte y dos de iulio, domingo por la mañana [RM 186.8]

Año de ciencuenta y tres en doze días de enero [RM 634]

De manera similar, en otras dos coplas sefardíes encontramos formulaciones semejantes, valiéndose del mismo método. La primera pertenece a una copla compuesta por Sa adí Haleví sobre un incendio acaecido en Salónica en 1890 y el posterior socorro a los quemados.

\section{En dieź y mueve elul ${ }^{7}$ šečentos y cicuenta [ER 333]}

La segunda pertenece también a otro desastre natural, de nuevo un incendio, acaecido en Constantinopla en 1883:

\section{Año de sečentos y cuarenta y cuatro [ER 326]}

Debemos tener en cuenta que en todas estas relaciones sefardíes la fecha que figura corresponde al cómputo del calendario judío, que «cuenta los años desde una supuesta fecha de la Creación del mundo, calculada a base de sumar las edades de las generaciones mencionadas en la Biblia» (Díaz-Mas y De la Puente 2007: 70) ${ }^{8}$.

Como ya apuntábamos más arriba, la oralidad va a jugar un papel muy destacado en la transmisión de todas estas obras. Ya desde la Edad Media, en Castilla, textos de muy diversa naturaleza se leían en voz alta, se cantaban o se recitaban, normalmente ante un grupo de oyentes más o menos numeroso. Las referencias a la lectura y a la recitación, a oír, a escuchar, etc. son abundantes en la literatura medieval española, pero también europea (Zumthor 1989). Por otra parte, la práctica de la lectura de un texto en voz alta desde siempre ha sido habitual entre los judíos.

En las relaciones de sucesos hispánicas y en las coplas sefardíes hemos encontrado casos como los siguientes:

Relaciones de sucesos hispánicas

Oigan todos, paren mientes, estad atentos a oír [RM 542]

El cielo inspire mi canto y mi tosca pluma rija [RM 104]

Quiero contar y no qüentos, sino verdades que escrivo [RM 236]

\section{Coplas sefardies}

Oíd coplas nuevas por el mal de Francia [ER 171]

Ordenar quero un cantar con gran yoź y brama [ER 339]

Empezar quero a contar una maravía

[ER 207]

7. En el calendario judío los meses son lunares y, por lo tanto, no coinciden exactamente con los del calendario gregoriano. Elul se corresponde con los meses de agosto/septiembre.

8. Para calcular a qué año judío corresponde un año gregoriano hay que sumarle $3760 \mathrm{y}$, viceversa, si queremos saber a qué año gregoriano corresponde un año judío, hay que restarle al año judío 3760 . 
Estas exhortaciones y fórmulas son muy frecuentes en estas obras lo que explica que, a pesar de que estas piezas se difundieron, principalmente, de forma impresa -en pliegos de cordel o libritos aljamiados-, la oralidad y la recitación en voz alta es un elemento consustancial de este tipo de composiciones. Es cierto que existían lecturas privadas, individuales y en silencio, pero estas composiciones ponen de relieve que, durante siglos, en diferentes culturas y latitudes, las lecturas en voz alta, de carácter público fundamentalmente, tuvieron una importancia más que destacada (para el caso espańol, véase Frenk 1997). No olvidemos que las transmisiones orales y escritas, ya fueran manuscritas o impresas, convivieron durante siglos (Bouza 2000, véase también Ong 1987). A ello hay que añadir que, en ambas culturas y durante siglos, tanto los manuscritos como los impresos sirvieron, en buena medida, para apoyar la recitación en voz alta, para fijar esos textos y facilitar la memorización. La voz, la palabra, el hablar el leer y el oír son elementos consustanciales a todas estas manifestaciones (Sánchez Pérez 2006a: 146). Los exordios de estas composiciones son buena muestra de que, a pesar de ser poemas impresos, se escuchaban, se recitaban, se cantaban o se salmodiaban. Así pues, fenómenos semejantes se dieron en una y otra cultura, a pesar de que tanto las relaciones como las coplas no poseen la oralidad como determinante de género, por ello podremos conocer

\footnotetext{
diferentes testimonios escritos y/o versiones orales, pero unos y otras no son más que resultado de la copia o de un aprendizaje memorístico del texto, cuya variación es de tipo mecánico y no supone una recreación a través de las variantes, como es determinante en la literatura tradicional de transmisión oral (Hassán 1987: 116).
}

Continuando con nuestro análisis, por lo que respecta a la narratio encontramos también interconexiones entre las relaciones de sucesos hispánicas y las sefardíes. Desde el punto de vista temático ya señalamos que, en ambos casos, habíamos partido de narraciones históricas y noticieras, reales o ficticias, pero verosímiles. Son obras que cuentan sucesos y hechos destacables que afectan a la historia de un país o de una comunidad. En castellano, tenemos, por ejemplo, relaciones sobre guerras, paces, batallas, victorias, etc., relaciones sobre desastres naturales: incendios, tempestades, terremotos, etc.; en judeoespañol encontramos relaciones sobre los mismos temas, así entre otros, el asedio de Belgrado de 1688, la independencia de Grecia (1821-1831), el incendio de Salónica de 1839, el terremoto de Constantinopla de 1884, etc.

Tanto los autores de las relaciones noticieras castellanas como los de las sefardíes sabían que para que su discurso surtiera efecto debía incluir en su narración todos aquellos elementos destinados a dirigir la atención y persuadir a los lectores y oyentes de estas coplas. Existe un propósito de deleitar (delectare), en muchos casos enseñar (docere), pero también -y lo que es a veces más importante- de suscitar una participación emotiva (movere) ante el auditorio. Tanto las relaciones de sucesos hispánicas como las coplas sefardíes parten de un suceso verosímil, lo que repercute en el propósito de instruir y deleitar, pero 
también en promover una participación emotiva. Los autores de estas obras saben que para que su discurso surta efecto debe suscitar toda una serie de pasiones en su auditorio (pathos). La persuasión debe canalizarse atendiendo a las reacciones emocionales del público (Sánchez Pérez 2005: 228). Es fácil comprender la reacción emotiva que provocarían mensajes como los que veremos a continuación, presentando ante los ojos de los oyentes y lectores los estragos del siguiente desastre natural’:

\section{Coplas sefardies}

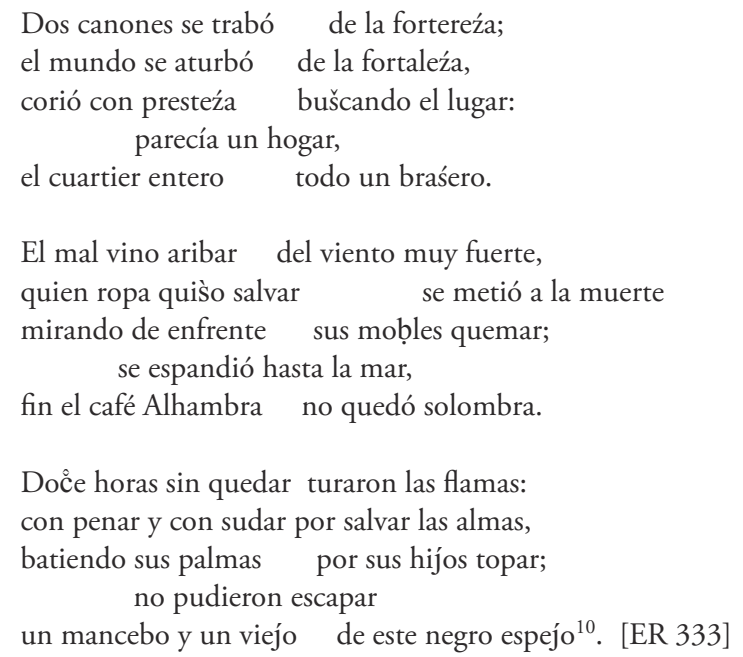

Recordemos las palabras de Elena Romero que resumen los hechos que acontecieron durante este incendio:

El 4 de septiembre de 1890, a las seis y media -no sé si de la mañana o de la tardeel fuego estalló en el barrio de La Placeta y, al oír los cañonazos con que en Salónica se anunciaba el estallido de un incendio, la gente corrió a ver lo que pasaba. Avivado por el fuerte viento, el fuego se extendió hasta el mar, quemando todo a su paso hasta llegar al café Alhambra; durante las doce horas que duró, la población, entre lloros y lamentos, intentó en vano salvar sus pertenencias y encontrar a sus hijos entre el tumulto [...] (ER 331).

La emoción presente en la obra nos ayuda a imaginar el patetismo que sentirían quienes leyesen o escuchasen estas coplas. Podemos intuir que sentimientos semejantes a la tristeza o la melancolía que sugiere este texto se produciría entre quienes oyesen esta relación de sucesos hispánica del siglo Xvi que narra otro desastre natural. Se trata de una tormenta acaecida en Constantinopla. Veamos un fragmento:

9. Ya puso de manifiesto estas similitudes Pedrosa 1995: especialmente pp. 347-352.

10. Aclaramos el significado de aquellas palabras que puedan ofrecer alguna dificultad al lector: canones 'cañones'; se trabó 'se dispararon'; cuartier 'barrio'; fin 'hasta'; negro 'malo'. 


\author{
En Constantinopla fue \\ una tempestad esquiva \\ y sabe Dios el porqué \\ más que se juntáronle \\ los cuatro vientos de arriba. \\ Derribaron de la ciudad \\ casa fuertes infinitas \\ torres de gran magestad \\ derribó esta tempestad \\ casi el Serrallo y mezquitas. \\ Fue tan escuro aquel día \\ que todos de miedo llenos \\ creyeron qu'el mundo ardía \\ pues del cielo descendía \\ rayos, relámpagos, truenos $[\ldots]$ \\ Las mugeres davan gritos \\ que era lástima y dolor \\ y los niños pequeñitos \\ desconsolados y aflictos \\ todos llenos de temor. \\ Fue tanta la escuridad \\ y el grave temblor de tierra \\ y el viento y bravosidad \\ que huían de la ciudad \\ a las cuevas de la sierra. \\ Anduvo este viento tanto \\ que a todos los destruyó \\ yo no sé quanto duró \\ pero fue cosa de espanto \\ la gente que pereció. [RM 276]
}

En el caso de la composición en judeoespañol podemos afirmar que nos hallamos ante unos hechos ocurridos realmente, más difícil resulta, sin embargo, conceder credibilidad a la relación castellana, ya que los desastres acaecidos en tierras «del turco» -como ellas mismas selañan- conllevan una ideología doctrinal y profética de índole antimusulmana a la que no nos vamos a referir ahora ${ }^{11}$.

Nos interesa, de nuevo, destacar los aspectos formales y poético-retóricos que caracterizan ambas composiciones. El pathos aristótelico es claramente perceptible en estas dos narraciones, debido a la carga de padecimiento y angustia que transmiten. Es probable que los autores de estas obras supiesen que la emoción que se presenta en ambas obras despertaría una especial conmoción en quienes las escucharan. La congoja y ansiedad que pueden provocar estas

11. No nos detenemos ahora en estos aspectos que rodean a la invención y difusión de este tipo de desastres naturales en la península Ibérica durante los últimos años del siglo Xvı, para ello véanse Sánchez Pérez 2006b y, especialmente, Puerto Moro 2008. 
composiciones a un auditorio de la época dota a la narración de un carácter patético de gran valor simbólico. Para conseguir este efecto los autores suelen recurrir, como en este caso, a la evidentia. Este procedimiento retórico es de suma utilidad para que el lector u oyente de estas obras se sienta como alguien que las observa con sus propios ojos, como un testigo presencial de los hechos narrados. De este modo, se provocará un efecto de visualización que lo inducirá a ciertos estados de ánimo o lo moverá a adoptar una determinada actitud. El auditorio se convierte así en espectador, en un testigo ocular de los hechos reproducidos. La evidentia, para Quintiliano era «una pintura de las cosas hecha con expresiones tan vivas, que más parece que se percibe con los ojos que con los oídos» (apud López Grigera 1994: 135). Veamos dos ejemplos más de signo muy distinto, pero que reflejan, en nuestra opinión, esa evidentia, así como las características fundamentales que asemejan a estas composiciones, atendiendo a los aspectos que hemos señalado anteriormente respecto al exordio y la narratio:

\section{Coplas sefardies}

Escuchés la buena ĝente que en catorće de $a b$ de ver ir chicos y grandes cativos de el quésar.

Mirá bien lo que pensar y nueva alguaya alzar, que caímos sin pensar en poder de el quésar.

Bien me duele mi corazón de ver tanta probeldad, hombres y tanbién mujeres, comimos léhem ŝar.

Mirá bien. esta sentencia tan negra

Belogrado decendiera

y toda la parentera

Grande dolor era ésta que no había otra tal,

De ver chicos y grandes y familla comimos léhem sâr ${ }^{12}$. [ER 88]

Relaciones de sucesos hispánicas

Del celeste consistorio, de la soberana cumbre, imploro el sacro adjutorio

según tengo de costumbre para un caso muy notorio. Y pues que no mereció esta lengua pecadora la gracia que a Dios pidió,

12. Negra 'mala'; ab 'julio/agosto' [Elena Romero identifica el 14 de ab de 5448 con el 10 de agosto de 1688]; quésar 'césar'; alguaya 'grito, queja'; léhemsar 'pan de la aflicción'. 


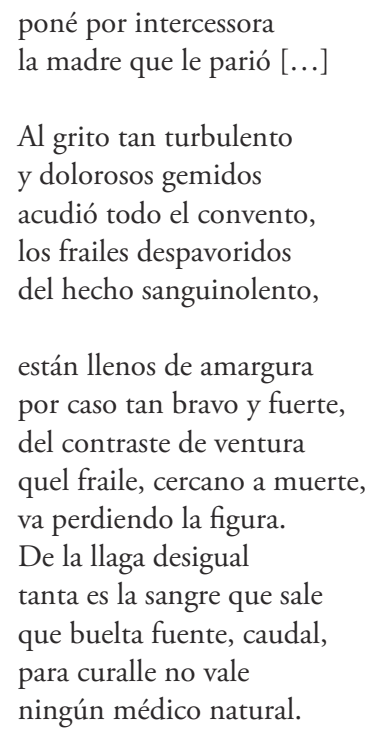

Parece claro que existe un uso -consciente o inconsciente- por parte de los autores de estas obras de seguir algunas pautas, de utilizar algunos recursos retóricos que eran ya conocidos desde la Edad Media. Los tratados medievales recuperaron los postulados de Cicerón, de la Rethorica ad Herennium y de otras obras similares. Además, en el caso de la Península Ibérica, todas estas directrices las utilizaron en las artes praedicandi, con las que se instruyó a monjes y predicadores ya desde el siglo XIII y, sin duda, los autores de las relaciones hispánicas se beneficiaron de la retórica de los sermones de la época, como veremos a continuación.

Por último, en la peroratio, epílogo o conclusión del discurso, normalmente no hemos encontrado fines bruscos, sino cierres en los que el autor pretende excitar las pasiones de su auditorio. Según las antiguas retóricas estos epílogos solían contener dos partes: por un lado, una recapitulación y enumeración de los temas tratados y, por otro, el movimiento de los afectos, en muchas ocasiones con una última alabanza a la providencia divina. En los ejemplos que hemos analizado no hemos encontrado ninguna recapitulación propiamente dicha, pero sí son abundantes los epílogos que refieren, de nuevo, una invocación a la deidad:

Relaciones de sucesos hispánicas

Desterrad los malos vicios, hombres, de vuestra memoria, porque son del mundo [escoria.

Hazed santos regozijos y daros ha Dios la gloria. [RM 231]

\section{Coplas sefardies}

Ya mos arepentimos de aqueas hablas
de quitar fama mala por la Tiera Santa.
¡Ah, Señor del mundo, fragua la Caśa santa!
Y daremos loores ${ }^{13}$. [ER 149]

13. Caśa santa "Templo de Jerusalén". 
Sirvamos a Dios eterno como somos obligados, para que del crudo infierno

podamos ser libertados para el siglo sempiterno. [RM 94.5]
Tefilá hagan todo Yisrael que mos mande ya al muestro goel y mos fragüe el Bet hamicdáš de golat Ariel, habtahá tenemos en el $\mathrm{Dio}^{14}$. [ER 116]

Con este tipo de cierres se trata, en muchas ocasiones, de «desarraigar vicios y arraigar virtudes en el alma» (Herrero Salgado 1996: 166), especialmente notable en el caso de las relaciones de sucesos hispánicas. Con todo, lo más frecuente tanto en estas últimas como en las coplas sefardíes es habitual el cierre haciendo referencia a la divinidad para mover la piedad entre los oyentes. En las relaciones castellanas es muy común que la narración concluya con la alabanza de la bondad de Dios, con los bienes que se obtienen gracias a la confesión, con los peligros que supone apartarse de la doctrina cristiana y la posibilidad de padecer los castigos eternos del infierno, etc. En este sentido afirmaba Ma ${ }^{a}$ Cruz García de Enterría que las «exhortaciones para tener devoción a la Virgen, para acudir a una comunión frecuente, para defenderse de las tentaciones del Diablo y cosas semejantes nos recuerdan inevitablemente y de nuevo la predicación» (García de Enterría 1990a: 288). En efecto, ya ha sido puesto de manifiesto en diversas ocasiones las similitudes y concomitancias que se observan entre estas relaciones de sucesos en pliegos sueltos poéticos y los sermones de la época (entre otros, García de Enterría 1990b y Cátedra 2002).

En el caso de las coplas sefardíes hemos encontrado gran número de conclusiones en las que se observa la alabanza al Dio, unido, en ocasiones, con la esperanza en la llegada del mesías ${ }^{15}$, la restauración del Templo de Jerusalén y el regreso de los judíos a su antigua tierra. El hecho de que se produzcan estos cierres se ajusta a la perfección a la propia mentalidad de los judíos, ya que, desde siempre, su vida ha estado prescrita y fijada por la religión. La lectura de textos religiosos y

la actitud de los sefardíes hacia el libro y la lectura viene determinada por su condición de judíos. Un elemento fundamental de la práctica religiosa judía [...] es la lectura de textos religiosos: la Torá que se lee en la liturgia sinagogal [...], cualquier otro escrito destinado a la lectura individual o colectiva, en el ámbito privado o doméstico, que pueda servir para aprender, recordar, reflexionar sobre la vida del judío o para alabar a Dios (Díaz-Mas 2004: 94).

14. Tefilá "oraciones"; goel "redentor"; Bet hamicdás "el Templo"; golat Ariel "diáspora de Ariel", es decir, "el pueblo judío"; habtaháa "confianza".

15. Existe una opinión formada muy extendida de que los judíos se diferencian, entre otras cosas, del cristianismo porque todavía esperan la llegada del Mesías. Esta idea no es del todo correcta puesto que «en el judaísmo -incluso en las corrientes más mesiánicas- el mesías nunca es Dios, ni hijo de Dios [...], sino un simple ser humano, líder y guía espiritual del pueblo judío. La idea de un mesías divino choca por completo con el estricto monoteísmo judío y es, precisamente, uno de los rasgos que contribuyeron a la escisión del cristianismo primitivo con respecto a sus orígenes judíos» (Díaz-Mas \& De la Puente 2007: 76). 
Mediante el análisis de estos fragmentos hemos podido observar buena parte de las concomitancias que se observan entre el género de las relaciones de sucesos hispánicas y el de las coplas sefardíes. No obstante, desde el punto de vista formal debemos destacar que existe una diferencia prácticamente absoluta entre los modelos métricos que utilizan una y otra cultura. De este modo, en las relaciones hispánicas encontramos, de manera abundante, el uso del verso del romance, así como la forma estrófica denominada como quintillas dobles o coplas de ciego (Baranda 1986) -no es frecuente la utilización de estrofas cultas en este tipo de obras-, mientras que en las coplas en judeoespañol son muy variados los esquemas estróficos usados por los sefardíes. Así, por ejemplo, un adorno muy frecuente en muchas de estas coplas es el uso del acróstico ${ }^{16}$, existen estrofas de tercetos monorrimos de verso largo amétrico, cuartetas octosilábicas con rima alterna, la denominada como estrofa de Purim ${ }^{17}$, etc. Por lo tanto, uno de los ragos formales que, sin duda, diferencia a las relaciones de sucesos hispánicas de las coplas sefardíes es el esquema métrico que utiliza una y otra tradición.

Hasta ahora hemos visto qué ocurre cuando nos hallamos ante los inicios -conocidos- de estas dos manifestaciones literarias. Sin embargo, ¿estos ragos formales y retórico-poéticos se mantuvieron en la tradición hispánica en siglos posteriores? Veamos algunos ejemplos ${ }^{18}$. En la segunda mitad del siglo XIX, concretamente en 1870 , se imprimió en Lérida un "caso horrible y espantoso» que comienza:

\author{
O dulce Jesús, divino \\ Redentor y padre amado, \\ dadme gracia porque esplique \\ el más horrible atentado \\ que sucedió en Aragón, \\ según me han relacionado.
}

En esa misma época encontramos otra relación de sucesos titulada Horrorosos asesinatos cometidos por Cristóbal Piqueras en Fuente Alvilla, provincia de Albacete, el día 4 de octubre del presente año; habiendo encontrado á un joven amancebado con su esposa, dió muerte á él y á cuatro hijos, y él mismo se ahorcó, como lo verá el lector. Esta obra comienza con los siguientes versos:

16. «Hay que tener muy en cuenta, naturalmente, que estamos hablando de coplas pensadas y creadas en lengua sefardí y escritas en grafía aljamiada, de modo que el orden de las letras no será estrictamente alfabético sino propiamente 'alefático', y que en los textos transcritos, para hallar el acróstico habrá que 'destrancribirlos' a su originaria aljamía hebraica» (Hassán 1987: 107). Las comparaciones entre el acróstico sefardí y el hispánico pueden verse en Pedrosa 1995.

17. Se la denomina de este modo por ser la estrofa caraterística de las coplas que aluden a esta celebración religiosa y «está formada por nueve versos cortos que riman [...] $a-b-a-b-b-c-c-d-d$. Combinando esta rima con una medida de los versos en la que alternen los de ocho y seis sílabas según el esquema 8-6-8-6-6-6-8-6-6 [...]» (Hassán 1987: 110).

18. Hemos tomado todos estos ejemplos de Segura 1984. 

A ti, Virgen sacrosanta, madre de desamparados le pido dés auxilio quien sigue el camino malo. También le pido a tu Hijo, al vivo Verbo encarnado, me dé un fuerte valor por manifestar los casos más horrendos que se han visto en nuestro siglos pasados [...].

Como podemos observar, la tradición de iniciar la narración invocando a la deidad pervive en la tradición hispánica siglos después de las primeras manifestaciones que veíamos del Quinientos. Es cierto que a medida que avanza el siglo xix y en la primeras décadas del xx se advierte un uso menor de este tipo de introducciones $\mathrm{y}$, acomodándose más a las nuevas formas periodísticas, muchas de estas composiones se inician ya presentando cronológica y topográficamente el lugar donde se van a desarrollar los hechos. Sin embargo, es curioso observar cómo en un pliego de 1849 el mismo autor de la relación de sucesos declara al iniciar su composición:
Acomodándome al uso, por cierto muy santo y bueno, de implorar de Dios la gracia, con el auxilio supremo de la inmaculada Virgen, antes de contar un hecho, yo también á Dios invoco antes de hablar de un suceso que estremece el corazón $[\ldots]^{19}$

Por lo tanto, el autor de esta narración era ya plenamente consciente de que estos exordios respondían a unos usos formulísticos asentados desde antaño que, por pura tradición literaria, se habrían mantenido a lo largo de los siglos. Sin duda, se trata de un hecho muy significativo porque denota que los propios autores de estas obras poseían ya una conciencia clara de estar haciendo uso de unas determinadas formulaciones que se habían mantenido prácticamente inalteradas a lo largo de su historia. Y del mismo modo que ocurre con los inicios de estas relaciones encontramos también finales semejantes a los que ya se producían en el siglo xvi. Así, por ejemplo, todavía en el siglo xix encontramos la siguiente conclusión:

$$
\begin{aligned}
& \text { Este es el caso, mortales, } \\
& \text { aprovechad su doctrina, } \\
& \text { traigamos los Evangelios, }
\end{aligned}
$$

19. Puede escucharse una versión cantada de esta narración en Joaquín Díaz, Música en la calle, Fundación Joaquín Díaz, 2003. Concretamente se trata del tema 9 «La hermana del asesino". 
que es soberana reliquia,

Dios nos conceda su gracia

y después gloria divina.

Además de la similitud que se observa en los encabezamientos y en los epílogos de estas narraciones, otros aspectos estilíticos y retóricos que ya habíamos señalado, como el recurso del pathos o de la evidentia retórica, siguen manifestándose en todas estas narraciones:

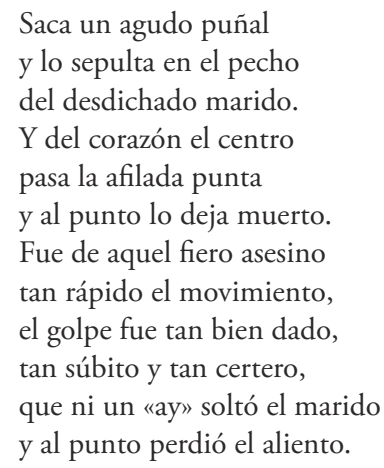

A través de todos estos ejemplos podemos afirmar que, como señaló José Manuel Pedrosa, «a la vista de todo ello, se va reforzando la impresión de que entre las coplas de cordel panhispánicas y las coplas sefardíes hay una evidente relación nominal, editorial, formal y estilística que prueba la influencia de un género sobre el otro" y, aunque también señala que todos estos paralelismos y concomitancias existen en estas producciones, no cabe duda de que en ambas manifestaciones existen aspectos específicos «y rasgos denotadores de personalidades propias y en buena medida autónomas» (Pedrosa 1995: 352). Por último, él señalaba:

La coincidencia en la denominación de coplas, en el formato editorial típico del pliego o pequeño folleto, en la naturaleza fundamentalmente narrativa, en los recursos propios de la escritura, en el estilo artificioso, en la función cantable, en recursos formales tan característicos como la estrofa, la rima o el uso del acróstico, en determinados contenidos ideológicos y morales, en funciones y temas comunes como el noticierismo o las catástrofes naturales, nos permiten concluir que existe una relación de influencia formal y funcional efectiva entre la poesía de cordel hispana y las coplas sefardíes (Pedrosa 1995: 356).

Las concomitancias y parelelismos entre las relaciones de sucesos hispánicas y las coplas sefardíes son evidentes. Ahora bien, cabe preguntarse de dónde les vienen a ambas tradiciones estos patrones comunes. Por una parte, es cierto que las comunicaciones entre el mundo hispánico y los sefardíes de la diáspora se mantuvo viva, en cierta medida, después de la expulsión, pero hay que tener en cuenta también que la mayor parte de los sefardíes de Oriente, en el siglo XVIII, desconocían prácticamente la literatura española contemporánea y la de épocas pasadas, con lo cual, parece poco probable que pudieran inspirarse directamente en fuentes hispánicas. 
Recordemos que, como ya hemos señalado, desde la Antigüedad en el exordium era común la imploración a la deidad o a las musas antes de comenzar culquier obra. Los exordios, por lo tanto, eran ya muy parecidos y estaban prácticamente establecidos desde la Alta Edad Media. Por lo que se refiere a la narratio, ya la tratadística medieval había rescatado -como decíamos anteriormente- los preceptos poético-retóricos estipulados desde la antigüedad latina. Así, por ejemplo, el cumplimiento de una serie de cuestiones que permitían una exposición narrativa canónica: quién (quis?), qué (quid?), por qué (cur?), dónde (ubi?), cuándo (quando?), cómo (quemadmodum?) y con qué medios o instrumentos (quibus adminiculis?). Esta serie de circunstancias, relacionadas con persona, factum, causa, locus, tempus, modus y facultas, fueron extraídas de la obra de Cicerón De inventione y eran ya conocidas en la Edad Media, puesto que se consideraban un aspecto fundamental de la retórica judicial. Pensemos, además, que existen semejanzas entre las prácticas antiguas y las actuales, pues hoy en día, en nuestros periódicos se consignan de igual modo estos elementos: «recuérdese, en concreto, la regla de las cinco W' de los reportajes periodísticos ingleses, compendiada en los interrogativos who, what, when, where, why, que corresponden a las cinco primeras preguntas latinas» (Garavelli 2000: 79). De este modo, unos patrones de la antigüedad latina han llegado básicamente hasta hoy. También Cicerón y la Rethorica ad Herennium habían convenido diferentes cualidades en la narratio, como son la claridad y la verosimilitud, así como el uso de la evidentia que, como hemos comprobado, aparece tanto en unas manifestaciones como en otras. Esto por lo que se refiere a la narratio, pero lo mismo podemos decir con respecto a la conclusión de estas narraciones hispánicas y sefardíes, pues también desde la Edad Media era frecuente que en los epílogos se volviera a agradecer a la divinidad para mover a la piedad entre los oyentes y lectores.

Los inicios de las relaciones de sucesos se remontan a las epístolas de relación medievales (Cátedra 1996), pero en el caso de las coplas sefardíes sus orígenes no son muy claros, aunque existen textos poéticos castellanos medievales que suponen un lejano antecedente y, debido a la nula existencia de productos editoriales en el siglo XVII, cabe la hipótesis de que hubo «un período de vida latente que enlazase sin interrupción las coplas medievales y las sefardíes» (Díaz-Mas 2006: 167). Ya desde la Edad Media había unos usos retóricos muy extendidos y tradicionalizados y, por lo tanto, para narrar asuntos parecidos se utilizaron recursos similares. De esta manera, esta tradición retórica se inició antes de 1492 y es probable que haya podido pervivir en ambas comunidades -la hispánica y la sefardí- durante siglos, a pesar de las distancias espaciotemporales.

Existen rasgos comunes, pero también diferenciadores, desde la utilización de distintos esquemas estróficos hasta, lo que parece más importante, la autoría de unas y otras composiciones. Frente a copleros populares hispánicos, en las coplas sefardíes nos las habemos, en ocasiones, con que el autor es un rabino perteneciente a la élite cultural e intelectual sefardí. Existe influencia de esa 
herencia común medieval, pero también signos denotadores de desarrollos posteriores e independientes en ambas manifestaciones.

Lo que parece evidente es que ambas manifestaciones estaban pensadas para deleitar, para instruir y para mover los afectos -fines ya establecidos desde la Edad Media-, pero, obviamente, a medida que avanza la historia se añaden otros objetivos -más acordes con los nuevos tiempos-, como pueden ser informar, entretener o también, por ejemplo, en el caso de los sefardíes, de mantener viva la memoria de los sucesos que afectaron a sus comunidades.

\section{Bibliografía citada}

Baranda Nieves, «Andanzas y fortuna de una estrofa inexistente: las quintillas dobles o coplas de ciego", Castilla 11, 1986, págs. 9-36.

Benbassa Esther \& Aron Rodrigue, Sephardi jewry: a history of the Judeo-Spanish community, 14th-20th centuries, Berkeley: University of California Press, 2000.

Bouza Fernando, Corre manuscrito: una historia cultural del Siglo de Oro, Madrid: Marcial Pons, 2001.

- Comunicación, conocimiento y memoria en la Espańa de los Siglos XVI y XVII, Salamanca: Seminario de Estudios Medievales y Renacentistas, 2000.

Cátedra Pedro M. (2002), Invención, difusión y recepción de la literatura popular impresa (siglo XVI), Mérida: Editora Regional de Extremadura.

- (1996), «En los orígenes de las epistolas de relación», en Ma. Cruz Gracía de Enterría et al., Las relaciones de sucesos en España (1500-1750), París \& Alcalá de Henares: Publications de la Sorbonne \& Publicaciones de la Universidad de Alcalá, pp. 3364.

Díaz-Mas Paloma, Los sefardies. Historia, lengua y cultura, Barcelona: Riopiedras, 2006.

— «El libro y la lectura entre los sefardíes de Oriente», en López-Vidriero, $\mathrm{M}^{\mathrm{a}}$. Luisa \& Pedro Cátedra (dirs.), La memoria de los libros. Estudios sobre la historia del escrito $y$ de la lectura en Europa y América, Madrid, Instituto de Historia del Libro y de la Lectura, vol. II, 2004, pp. 85-100.

- Poesía oral sefardí, Ferrol: Sociedad de Cultura Valle-Inclán, 1994.

Díaz-Mas Paloma \& Cristina de la Puente, Judaísmo e Islam, Madrid: Ares y Mares, 2007.

Ettinghausen Henry, «Hacia una tipología de la prensa española del siglo xvı: de 'hard news' a 'soft porn'”, en Ignacio Arellano et al. (eds.), Studia Aurea. Actas del III Congreso de la AISO (Toulouse, 1993), I, Plenarias. General. Poesía, Navarra: GRISOLEMSO, pp. 51-66, 1996.

Frenk Margit, Entre la voz y el silencio. (La lectura en tiempos de Cervantes), Alcalá de Henares: Centro de Estudios Cervantinos, 1997.

Garavelli, Bice Mortara, Manual de retórica, Madrid: Cátedra, 2000.

García de Enterría Ma. Cruz, «Retórica menor», Studi Ispanici 1987-1988, Pisa: Giardini, 1990a, pp. 271-291.

— «El cuerpo entre predicadores y copleros», en Augustin Redondo, ed., Le corps dans la société espagnole des XVI et XVII siècles, París: Sorbonne, 1990b, pp. 233-244.

Hassán Iacob M., «Un género castizo sefardí: las coplas», en Paloma Díaz-Mas, dir., 
Los sefardies. Cultura y literatura, Vitoria: Universidad del País Vasco, 1987, pp. 103123.

Herrero Salgado Félix, La oratoria sagrada en los siglos XVI y XVII, Madrid: Fundación Universitaria Española, 1996.

Infantes Víctor «¿Qué es una relación? (Divagaciones varias sobre una sola divagación)», en en Ma . Cruz Gracía de Enterría et al., Las relaciones de sucesos en España (15001750), París \& Alcalá de Henares: Publications de la Sorbonne \& Publicaciones de la Universidad de Alcalá, pp. 203-216, 1996.

López Grigera Luisa, La retórica en la España del Siglo de Oro, Salamanca: Universidad de Salamanca, 1994.

Méchuolan Henry, ed., Los judíos de España. Historia de una diáspora. 1492-1992, Madrid: Trotta, 1993.

Ong Walter, Oralidad y escritura. Tecnologías de la palabra, México: Fondo de Cultura Económica, 1987.

Pedrosa José Manuel, «Coplas sefardíes y pliegos de cordel hispánicos», Sefarad 55, 2, 1995, pp. 335-357.

Puerto Moro Laura, «La relación de catástrofes 'naturales’ y 'antinaturales’ como profecía anti-turca en pliegos sueltos poéticos del s. XVI», en Pierre Civil, Françoise Crémoux \& Jacobo Sanz, eds., España y el mundo mediterráneo a través de las relaciones de sucesos (1500-1750), Salamanca: Universidad de Salamanca, 2008, pp. 225-236.

Rodríguez Moñino Antonio, Nuevo Diccionario Bibliográfico de Pliegos Sueltos Poéticos. Siglo XVI, edición corregida y actualizada por Arthur L.-F. Askins \& Víctor Infantes, Madrid: Castalia \& Editora Regional de Extremadura, 1997.

Romero Elena, La creación literaria en lengua sefardí, Madrid, Mapfre, 1992.

- Entre dos (o más) fuegos. Fuentes poéticas para la historia de los sefardíes de los Balcanes, Madrid: CSIC, 2008.

Sánchez Pérez María, «A todos quiero contar | un caso que me ha admirado’: la convocación del público en los pliegos sueltos poéticos del siglo XVI», en La literatura popular impresa en España y en la América Colonial. Formas \& temas, géneros, funciones, difusión, historia y teoría, dirigido por Pedro M. Cátedra García, edición al cuidado de Eva Belén Carro Carbajal, Laura Mier, Laura Puerto Moro y María Sánchez Pérez, Salamanca: Seminario de Estudios Medievales y Renacentistas \& Instituto de Historia del Libro y de la Lectura, 2006a, pp. 145-159.

— «Noticias sobre desastres naturales: tormentas y tempestades en pliegos sueltos poéticos (Siglo XVI)», en Sagrario López Poza, ed., Las noticias en los siglos de la imprenta manual, A Coruña: SIELAE \& Sociedad de Cultura Valle-Inclán, 2006b, pp. 191-199.

— «La retórica de las relaciones tremendistas del siglo XVI», en Javier San José Lera (coord. y ed.), Praestans labore Victor. Homenaje al profesor Victor García de la Concha, Salamanca: Universidad de Salamanca, 2005, pp. 217-234.

— «La transmisión y difusión de los casos horribles y espantosos desde sus orígenes hasta el siglo xxI", en Ana Cabello et al., eds., En los márgenes del canon. Aproximaciones a la literatura popular y de masas escrita en español (siglos XX-XXI), Madrid: CSIC, Arbor y Los libros de la Catarata, 2011.

Segura Isabel, Romances horrorosos, Barcelona: Alta-Fulla, 1984.

Zumthor Paul, La letra y la voz. De la «literatura» medieval, Madrid: Cátedra, 1989. 